\title{
Pyruvate Kinase PKLR
}

National Cancer Institute

\section{Source}

National Cancer Institute. Pyruvate Kinase PKLR. NCI Thesaurus. Code C157139.

Pyruvate kinase PKLR (574 aa, $62 \mathrm{kDa}$ ) is encoded by the human PKLR gene. This protein plays a role in the transphosphorylation of phohsphoenolpyruvate into pyruvate and ATP in erythrocytes. 